\title{
APPLYING VALUE CHAIN ANALYSIS TO INFORMAL SECTOR RECYCLING: A CASE STUDY OF THE ZABALEEN
}

\author{
Remi Jaligot ${ }^{a}$, *David C. Wilson ${ }^{\text {a }}$, Christopher R. Cheeseman ${ }^{\text {a }}$, Berti Shaker ${ }^{b}$, Joachim Stretz ${ }^{\text {b }}$ \\ ${ }^{a}$ Department of Civil and Environmental Engineering, Imperial College London, United Kingdom \\ ${ }^{\mathrm{b}}$ Deutsche Gesellschaft für Internationale Zusammenarbeit (GIZ) GmbH, Cairo, Egypt
}

*Corresponding author. E-mail address: waste@ davidcwilson.com

\begin{abstract}
A methodology has been developed to apply value chain analysis (VCA) to the informal recycling sector, and demonstrated using the Zabaleen in Cairo, Egypt as a case study. The VCA methodology provides a 'toolkit' comprising four stages. The first involves mapping the value chain and has been demonstrated using the recycling of polyethylene terephthalate (PET) bottles as the particular example. Stage 2 tabulates the value added at each step in the value chain; this has been demonstrated for different types of plastics as well as other recycled fractions. Stage 3 identifies and then applies a set of indicators for the development of the informal sector recycling value chain in order to address technical and socio-economic challenges. The indicators proposed are in three categories: connections in the value chain, waste valorisation and the enabling environment. Stage 4 involves developing a system dynamic map that shows connections between the indicators, and the stocks and flow variables in the value chain. In particular, it identifies the most highly connected indicators on which to focus interventions, as these are likely to have the greatest impact on the overall system. For the Zabaleen, these are improving the quality of waste inputs into the value chain through source segregation, optimising access to waste and upgrading recycling activities through access to finance and technical knowledge.
\end{abstract}

Keywords: informal sector; solid waste management; recycling; value chain analysis; analytical tools; developing countries.

\section{HIGHLIGHTS}

- A new methodology applies value chain analysis (VCA) to informal sector recycling.

- The toolkit is demonstrated using the Zabaleen in Cairo, Egypt as a case study.

- The toolkit maps the value chain and then tabulates the value added at each step.

- Connections between a set of indicators is analysed using a System Dynamic Map.

- Development priorities: source segregation, access to finance, technical knowledge. 


\section{GRAPHICAL ABSTRACT}

\section{Applying value chain analysis to informal sector recycling}

\begin{tabular}{|c|c|c|c|c|}
\hline $\begin{array}{c}\text { Four-Stage } \\
\text { VCA tool-kit }\end{array}$ & $\begin{array}{l}\text { 1. Map the value } \\
\text { chain }\end{array}$ & $\begin{array}{l}\text { 2. Value added at each } \\
\text { step in the value chain }\end{array}$ & $\begin{array}{l}\text { 3. Indicator set for } \\
\text { value chain } \\
\text { development }\end{array}$ & $\begin{array}{l}\text { 4. System dynamic map } \\
\text { showing connections } \\
\text { between indicators }\end{array}$ \\
\hline
\end{tabular}

Mapping the Zabaleen value chain for plastic recycling
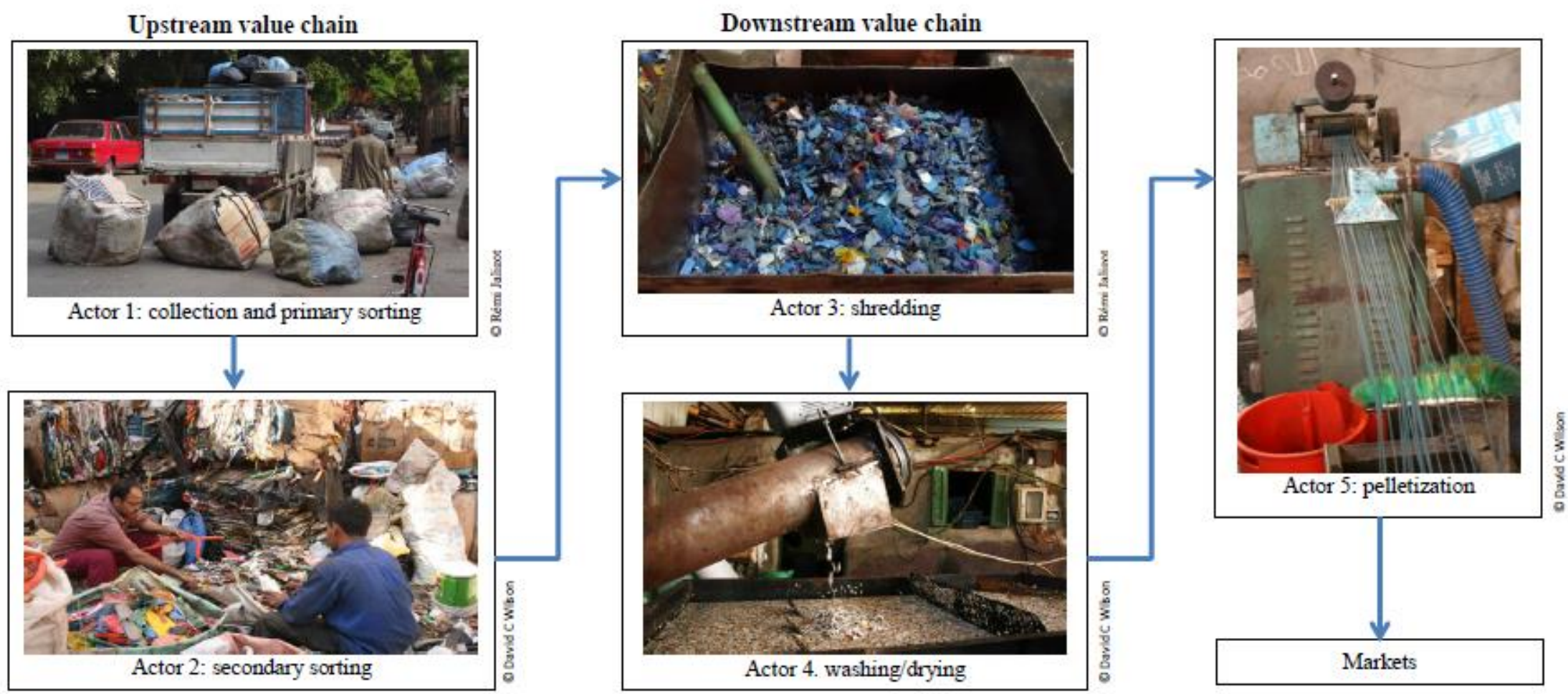


\section{INTRODUCTION}

Recycling is an integral part of sustainable waste management that can be a formal or informal sector valorisation activity (Wilson et al., 2013; UNEP, 2015). It relies on source segregation, collection, sorting, mechanical processing and trading into local, national and international industrial and agricultural markets (Scheinberg, 2012). The concept of waste valorisation is broader than the concept of recycling because it takes into account the commercialisation of recycled materials (Scheinberg, 2011, 2012). In developing countries valorisation activities are usually performed by informal recycling value chains (Medina, 2000, 2007; Ahmed and Ali, 2004; ILO, 2004; Wilson et al., 2006, 2009, 2012; Gutberlet, 2008, 2015; Samson, 2010; Scheinberg et al., 2010; Gunsilius et al., 2011a; Ezeah et al., 2013; Linzner and Lange, 2013; Schluep, 2014; Rodic, 2015). Developing the value chain is essential to fully integrate the informal sector into the waste management system (Velis et al., 2012).

Scheinberg uses the term 'value chain recycling' to describe private sector recycling activities that depend solely on the revenues from selling recovered materials, as opposed to municipal recycling where the economics is driven also by the price of competing alternative disposal routes (Scheinberg and Simpson, 2015). Informal sector recycling in developing countries often exists independently of the formal municipal solid waste management sector, seeking otherwise unoccupied economic niches within the formal industrial or agricultural value chains (Scheinberg, 2011). Much of the literature explores opportunities for inclusion or integration of informal recyclers within the municipal solid waste management system (e.g. Gunsilius et al., 2011b; Scheinberg et al., 2011; Scheinberg, 2012; Mavropoulos et al., 2014; Scheinberg and Savain, 2015). Velis et al., (2012) present a framework for use in designing interventions, while Scheinberg and Simpson (2015) have developed a visualisation tool which examines the degree of overlap of the service and value chains. Cohen et al., (2013) provide an operational guide for preparing an informal sector inclusion plan.

The position of informal sector recyclers is often at the beginning of the value chain, collecting dirty materials for sale at a low price to which others add value. Value chain analysis (VCA) has been widely used in agriculture to help improve the livelihoods of poor farmers (Kaplinsky and Morris, 2001; KIT et al., 2006; Riisgaard et al., 2011; Trienekens, 2011). VCA originates from the work of Porter (1985, 1990) and Womack and Jones (1996). Kaplinsky and Morris (2001) defined a value chain as "the full range of activities which are required to bring a product or service from conception, through the different phases of production (involving a combination of physical transformation and the input of various producer services), delivery to final consumers, and final disposal after use". Each step or link in the value chain involves a source input, a process of value addition and selling the material to the next link in the chain. Each step adds value to the product and often generates more revenue than the previous step. VCA seeks to identify the different steps and actors in the value chain 
and evaluate their performance. This allows an analysis of how to improve the livelihoods of those upstream, towards the beginning of the chain, for example by modifying particular steps within the chain and the interactions between them (Humphrey and Navas-Alemán, 2010).

The potential for application of VCA to the informal recycling sector has been recognised (Velis et al., 2012), but so far most work has appeared in the grey literature, is unpublished or is relatively narrow in scope. VCA was applied in a qualitative manner to cardboard recycling in Durban (Mueller, 2005). It was used to study plastics recycling in Delhi (Bagadayeva, 2009) and has been used as a framework to study the informal recycling sector in India (Dr Sanjay Gupta, personal communication, 2011). The GTZ (now GIZ) Private Sector Development Programme prepared a Value Chain Development (VCD) tool, again primarily for application in the agricultural sector (Will et al., 2008). This was applied to the plastics recycling sector in Egypt (Staffeld, 2010). CHF International (2012) applied a specific version of VCA to examine the youth job creation potential of SWM interventions in Accra, Ghana. Rakiman et al., (2014) used qualitative VCA to examine aluminium recycling in developed countries and Rigasi et al., (2015) used a qualitative version of VCA to analyse and propose improvements to informal sector recycling in Nigeria.

The primary aim of this research was to develop a framework for applying Value Chain Analysis (VCA) to informal sector recycling. This required the selection of a practical case study, as the development and demonstration of the component VCA methods are inextricably linked. The ideal situation would be to study a local informal recycling sector that has already made substantial progress in developing additional value added steps beyond the simple collection of materials to sell on for recycling, and therefore this research has focussed on the Zabaleen recycling community in Cairo, Egypt.

The Zabaleen are a Coptic Christian community who first came to Cairo and Alexandria in the 1930s. They have traditionally provided a door-to-door waste collection service for a fee to higher-income households. However, their main source of income is from sorting the waste and selling the recovered dry materials and raising pigs on the organic waste component. Local NGOs and international development agencies have been actively working with the Zabaleen since the 1980s, with an early Oxfam-funded project focusing on helping the Zabaleen to develop small businesses to add value to the raw materials they separate. This has resulted in a complex value chain within the Zabaleen community (Conrad and Joos, 2010; Didero, 2012; Schluep, 2014). The Zabaleen have received much international attention recently, particularly because of a long running 'conflict' with official efforts since 2002 to contract waste collection and disposal in Cairo to international private companies (Fahmi, 2005; Fahmi and Sutton, 2006, 2010; Ishkandar and Tjell, 2009). The Zabaleen in Cairo have been used as a case study in two major international GIZ studies of the informal recycling sector, one focusing on the economic aspects (CID Consulting Group, 2008; Scheinberg et al, 2010, 2011; Gunsilius et al, 2011a) and the other on integration opportunities (Gerdes and Gunsilius, 2010; 
Gunsilius et al., 2011b). A tool for financial and social cost-benefit analysis has previously been applied to the Zabaleen (Bowman et al., 2011).

The Zabaleen in Cairo represents about $80 \%$ of the total informal waste management sector in Egypt and there are currently six main active Zabaleen settlements collecting waste from the adjoining governorates of Cairo, Giza and Qalyubeya (collectively Greater Cairo) (Shaker, 2014a). Waste generation in Greater Cairo is estimated at 23,000 tonnes per day (Zaki et al., 2013), of which the Zabaleen collect just under $40 \%$.

The aims of the work reported here were thus to develop a method for applying VCA to the informal recycling sector, demonstrate the method by applying it to the Zabaleen and make recommendations from the VCA on how the informal sector recycling of the Zabaleen could be further improved.

\section{APPROACH}

The application of VCA to the informal recycling sector was developed from the use of VCA in the agricultural sector. The VCA methodology provides a 'toolkit' comprising four stages. The first two stages are adaptations of standard VCA methods. The third uses a categorisation adapted from previous experience, with the detailed selection of indicators based on knowledge gained from the case study in Cairo. The fourth stage allows identification of the critical indicators which are most highly connected and thus are likely to have the most impact on the overall value chain.

Background information on waste management in Cairo and on the Zabaleen recycling system was provided by the GIZ project team based in Cairo, who were in the fourth year of the National Solid Waste Management Programme supporting the Ministry of the Environment (GIZ, 2015). Interviews were conducted with a number of GIZ team members and other Egyptian solid waste management professionals. This information was supplemented by primary data collection carried out in Cairo in June 2015. A total of 45 semi-formal and informal interviews were conducted, including 22 interviews in small and medium recycling enterprises in the Zabaleen communities in Mokkatam and Ezzbat el Nakhl. The Zabaleen were asked how they perform their task, what could be improved, what they needed to expand their businesses and also to provide cost and other economic data. In addition, informal interviews were conducted with the residents of Zamalek, a high-income district in Cairo, in order to gain the perspective of service users about the current SWM system. 


\section{VCA TOOLKIT FOR THE INFORMAL RECYCLING SECTOR}

The four inter-linked stages used to apply VCA to informal sector recycling are summarised in Table 1.

Stage 1 maps the value chain. This is standard practice in VCA (Kaplinsky and Morris, 2001). This visualises the different steps/actors in a particular value chain and allows clear understanding of the connections between the actors. Mapping has previously been used by Mueller (2005) for cardboard recycling and to provide a generic overview of the sector (Scheinberg, 2011, 2012). A proprietary software package has been used in this work to standardise the process.

Stage 2 determines the value added at each step of (or by each actor in) the value chain. This is also standard practice in VCA (Kogut, 1985; Porter, 1985; Kaplinsky and Morris, 2001). The format of Staffeld (2010) was used to facilitate comparison of our data with 2010 data for the Zabaleen.

Stage 3 defines a set of indicators for the development of the informal sector recycling value chain in order to address both technical and socio-economic challenges. Indicators are in three categories, based largely on work by Lazzarini et al., (2001) and Sturgeon (2001) on value chain networks; Trienekens (2011) on agricultural value chains in developing countries; and Chang et al. (2011) on system analysis tools for solid waste management.

a. Connections in the value chain. In developing countries, there are usually poor connections between the value chain actors which hinder development of the value chain (Trienekens, 2011). Lazzarini et al., (2001) focussed on the concept of network structure, with strong horizontal and vertical connections.

b. Waste valorisation. This is adapted from the concept of value added at each step by the different actors in the value chain, as developed in Trienekens (2011) for the agricultural sector - the six recycling-specific indicators outlined later also used that paper as their inspiration and starting point.

c. Enabling environment. This concept was again detailed in Trienekens (2011). It is also consistent with previous work in the waste sector, both the Wasteaware benchmark indicators for assessing the overall performance of a city's solid waste management system (Wilson et al., 2015) and the analytical framework for integrating informal sector recycling developed by Velis et al., (2012). This category focuses on the essential broader sectorial and policy contexts. 
Table 1 - The four stage 'toolkit' developed to apply Value Chain Analysis (VCA) to the Informal Recycling Sector (IRS)

\begin{tabular}{|c|c|c|c|c|c|}
\hline Stage & Name & Purpose & Form of tool & $\begin{array}{c}\text { How presented in } \\
\text { this paper }\end{array}$ & Innovation \\
\hline 1 & $\begin{array}{l}\text { Map of value } \\
\text { chain }\end{array}$ & $\begin{array}{l}\text { Map the steps in the } \\
\text { value chain for a } \\
\text { particular recycled } \\
\text { material }\end{array}$ & $\begin{array}{l}\text { Flow diagram. } \\
\text { Use is made here of } \\
\text { Vensim } ® \text {, a system } \\
\text { dynamics modelling } \\
\text { software }\end{array}$ & $\begin{array}{l}\text { Example for PET } \\
\text { recycling in Cairo }\end{array}$ & $\begin{array}{l}\text { Standard practice in } \\
\text { VCA. } \\
\text { The use of Vensim }{ }^{\circledR} \\
\text { to ensure consistency } \\
\text { is novel. }\end{array}$ \\
\hline 2 & $\begin{array}{l}\text { Value added } \\
\text { at each step } \\
\text { in the chain }\end{array}$ & $\begin{array}{l}\text { Document } \\
\text { distribution of } \\
\text { income and benefits } \\
\text { along the value chain }\end{array}$ & $\begin{array}{l}\text { Table setting out } \\
\text { selling prices, added } \\
\text { value and revenues } \\
\text { for each link }\end{array}$ & $\begin{array}{l}\text { Three examples for } \\
\text { Cairo: in detail for } \\
\text { PET, in less detail for } \\
4 \text { types of plastic, and } \\
\text { in summary for all } \\
\text { materials }\end{array}$ & $\begin{array}{l}\text { Standard practice in } \\
\text { VCA. } \\
\text { The table format is } \\
\text { taken from Staffeld } \\
(2010) \text {, to allow easy } \\
\text { comparison of the } \\
2010 \text { and } 2015 \text { data }\end{array}$ \\
\hline 3 & $\begin{array}{l}\text { Indicator set } \\
\text { for value } \\
\text { chain } \\
\text { development }\end{array}$ & $\begin{array}{l}\text { Identify the barriers } \\
\text { and constraints to } \\
\text { informal sector } \\
\text { recycling, and } \\
\text { analyse potential } \\
\text { changes to address } \\
\text { those }\end{array}$ & $\begin{array}{l}\text { The three categories } \\
\text { have been adapted } \\
\text { from earlier work on } \\
\text { the agricultural } \\
\text { sector. } \\
\text { A generic set of } \\
\text { indicators applicable } \\
\text { to the IRS has been } \\
\text { developed in this } \\
\text { work, inspired by } \\
\text { field work in Cairo }\end{array}$ & $\begin{array}{l}\text { Derivation of the } 3 \\
\text { high-level categories } \\
\text { is discussed in this } \\
\text { section. } \\
\text { The generic set of } \\
\text { IRS indicators is set } \\
\text { out in Table } 6 \text {, and } \\
\text { their use illustrated } \\
\text { for the Cairo case } \\
\text { study }\end{array}$ & $\begin{array}{l}\text { High-level categories } \\
\text { adapted from earlier } \\
\text { work in the } \\
\text { agricultural sector. } \\
\text { The proposed set of } \\
\text { generic indicators for } \\
\text { the IRS is novel }\end{array}$ \\
\hline 4 & $\begin{array}{l}\text { System } \\
\text { Dynamic } \\
\text { Map, } \\
\text { showing } \\
\text { connections } \\
\text { between } \\
\text { indicators }\end{array}$ & $\begin{array}{l}\text { Map the connections, } \\
\text { in order to identify } \\
\text { the critical indicators } \\
\text { - i.e. those with the } \\
\text { greatest impact on the } \\
\text { system. } \\
\text { These critical } \\
\text { indicators represent } \\
\text { the key points of } \\
\text { intervention to } \\
\text { develop the value } \\
\text { chain. }\end{array}$ & $\begin{array}{l}\text { A system dynamic } \\
\text { map, showing all the } \\
\text { connections between } \\
\text { each indicator and the } \\
\text { stocks within the } \\
\text { value chain, the flow } \\
\text { variables and other } \\
\text { indicators. } \\
\text { Uses Vensim®, a } \\
\text { system dynamics } \\
\text { modelling software }\end{array}$ & $\begin{array}{l}\text { The system dynamic } \\
\text { mapping tool is } \\
\text { generic. } \\
\text { The version shown in } \\
\text { Figure } 2 \text { but was } \\
\text { developed following } \\
\text { the case study in } \\
\text { Cairo, so is presented } \\
\text { along with the other } \\
\text { tools. }\end{array}$ & Novel \\
\hline
\end{tabular}

Stage 4 involves the development of a system dynamic map, showing how each indicator influences the stocks within the value chain, the flow variables (the rate of change in the system for each step in the value chain) and other indicators. This is a novel contribution which facilitates interpretation of how the indicators influence the value chain. In particular, it identifies the most highly connected indicators on which to focus when developing interventions, as these are likely to have the greatest impact on the overall system. 


\section{DEMONSTRATING THE VCA TOOLKIT FOR THE ZABALEEN}

\subsection{Stage 1 - Mapping the value chain (using the example of PET bottles)}

The first two stages of mapping and documenting the value added at each step in the value chain were applied to the recovery by the Zabaleen of four different types of plastic, aluminium cans, scrap ferrous metals and tin cans, segregated paper, mixed paper/cardboard, organics and refuse derived fuel (RDF). For conciseness, the mapping tool is illustrated here for one example, polyethylene terephthalate (PET) bottles. Egypt is increasingly using PET bottles for water and other drinks, and this waste stream has grown substantially in recent years.

Figure 1 maps the PET value chain. It shows the steps in the value chain, beginning upstream on the left with the collectors and primary sorters, and moving through various intermediate trading and processing steps towards the recyclers who are downstream, on the right of the figure.

Upstream, 'actor 1' refers to the collectors who typically also carry out primary sorting of materials into categories (such as PET bottles), before selling the materials on, either to an intermediate trader or directly to a recycling workshop. The next step (actor 2) is secondary sorting, which in the case of PET bottles is typically into transparent and coloured categories. PET bottles have a large volume, so if the sorted materials are to be stored or traded with another party, then a compaction step is commonly carried out by actor 2 .

Downstream, the next two steps in the value chain for most plastics are shredding to a fairly standard particle size (actor 3), followed by washing/drying (actor 4). The shredding step further reduces the volume of the material for storage and transport, while the combination of the two steps prepares the material for further processing.

Secondary sorting, shredding and washing can be performed by different enterprises (actors 2, 3 and 4), or two or more of the steps can be completed within the same enterprise. Larger enterprises can integrate the steps and have significant advantages as they tend to have larger storage capacity (up to 100 tonnes, compared to 2 tonnes for the smaller enterprises), so they can collect large volumes of product to achieve a better price, and they can stockpile if demand is low. The technologies involved in both shredding and washing/drying are relatively complex and expensive. Water and electricity consumption costs are high, and so the technical and financial requirements favour larger enterprises which benefit from economies of scale. Smaller enterprises operating just one process tend to have ageing equipment and limited storage capacity, and are more likely to deal with local formal and informal product manufacturers, or with intermediate traders. 


\section{Upstream value chain}

\section{Downstream value chain}

Value Chain Stage

Actor 1

Actor 2

\section{Actor 3}

\section{Actor 4}

Markets

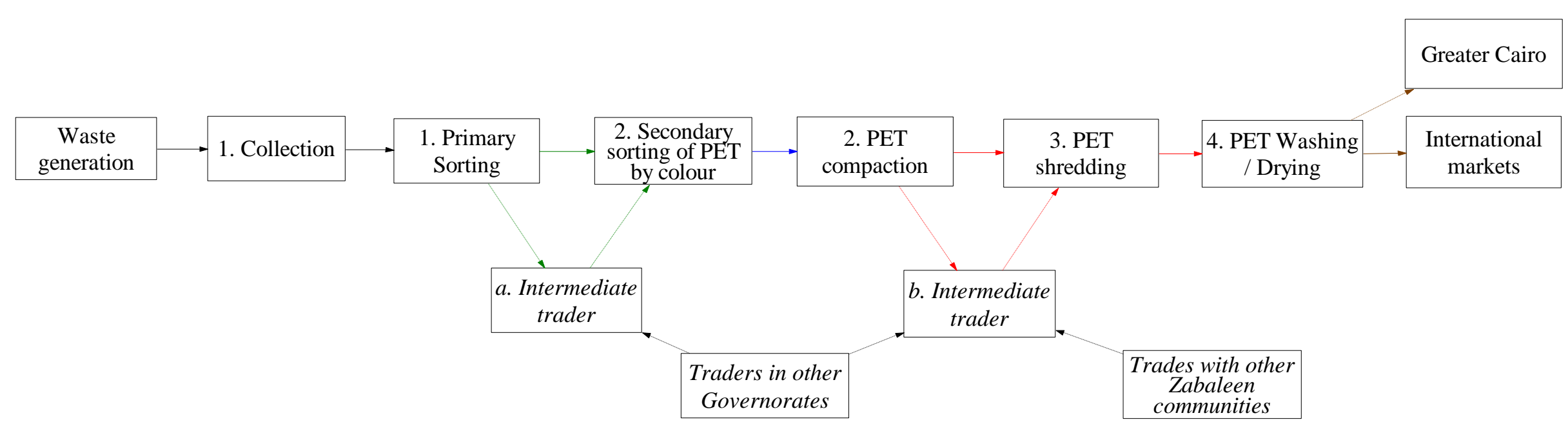

\section{Figure 1 - Map of the PET value chain in the Zabaleen}

The boxes show the individual steps or unit operations in the value chain, while the numbers indicate the different actors involved within the main (linear) value chain (excluding the intermediate traders). The figure shows that collection and primary sorting are both carried out by Actor 1 , and secondary sorting and compaction of the PET bottles by Actor 2 - these numbers are also used for cross-reference in Table 2 . Plain arrows are the main connections between the value chain steps and dashed arrows are the secondary connections. The 'upstream' value chain includes collection, sorting and compaction (Actors 1 and 2 ), and also the intermediate traders linking Actors 1 and 2 (box a.). The 'downstream' value chain includes recyclers performing shredding and washing/drying (Actors 3 and 4), and also intermediate traders (b), before the material is sold to an external market. PET is sold to market after washing/drying; for other types of plastic, there is an additional 'Actor 5', carrying out melting, extrusion and pelletization (collectively termed 'pelletization') within the Zabaleen settlement, prior to selling into external markets. 'International exports' remain viable outlet markets for PET even though the recent increase in export taxes and Chinese restrictions on import of materials of low quality forced the recyclers to re-direct trades to industries in Cairo. To ensure the consistency of value chain maps between materials, this map was created using Vensim®. 
Intermediate traders are present at many steps in the value chain. Most of the recyclers interviewed purchased recyclable materials directly from collectors/primary sorters and intermediate traders. The collectors/primary sorters and recyclers prefer to trade directly. The niche filled by intermediate traders is essential to deal with relatively small and regular purchases from a large number of collectors/primary sorters and also small secondary sorters. They provide storage space to accumulate larger quantities for which recyclers will pay a higher price.

Recovered PET is used to make textile fibres and the shredded and washed PET cannot be further processed within the Zabaleen community. This is in contrast to other plastics such as high- and lowdensity polyethylene (HDPE and LDPE) or polypropylene (PP), which have at least one further step in the 'internal' Zabaleen value chain involving melting, extrusion and pelletization (actor 5). The plastic pellets are generally sold as secondary raw materials, but there is some limited manufacturing within the Zabaleen community of low value products such as hangers and floor mats. PET is exported to countries with high demand such as China. However, this is constrained by high export taxes and increasingly stringent quality standards which can be difficult for the Zabaleen to achieve.

The PET example highlights a number of more general constraints faced by the Zabaleen. Low quality sorting is a major issue, with transparent PET unlikely to meet international standards. Problems are reliance on human recognition to separate different polymers manually; and contamination of the bottles, particularly by collars and caps. The demand for recycled PET is higher in the summer and autumn when it is used to make winter clothing. Coloured PET has a limited market. Profitability depends on having sufficient storage space to accumulate material and therefore intermediate traders and larger workshops/recyclers have an advantage.

\subsection{Stage 2 - Value added at each step in the value chain (Comparative revenue analysis)}

Table 2 shows the value added for transparent PET at each step in the value chain. Each row corresponds to one or more steps, with the numbers corresponding to those for the different actors in Figure 1. The left side of the table presents June 2015 data, while the right side provides corresponding data for June 2010 from Staffeld (2010). 
Table 2 - Value added for transparent PET at each step of the value chain

\begin{tabular}{|c|c|c|c|c|c|c|c|c|c|c|}
\hline \multirow{2}{*}{$\begin{array}{c}\text { Steps in the } \\
\text { PET Value Chain }\end{array}$} & \multicolumn{6}{|c|}{ June 2015 data from this work } & \multicolumn{4}{|c|}{ June 2010 data (Staffeld, 2010) } \\
\hline & $\begin{array}{l}\text { Selling } \\
\text { prices } \\
\text { per tonne } \\
\text { (LE) }\end{array}$ & $\begin{array}{l}\text { Process } \\
\text { Loss }(\%)\end{array}$ & $\begin{array}{l}\text { Gross } \\
\text { Revenue } \\
\text { per tonne } \\
\text { bought in } \\
\text { (LE) }\end{array}$ & $\begin{array}{l}\text { Revenue } \\
\text { per tonne } \\
\text { bought in } \\
\text { (LE) }\end{array}$ & $\begin{array}{l}\text { Net Value } \\
\text { added (\%) } \\
\text { per tonne } \\
\text { bought in }\end{array}$ & $\begin{array}{l}\text { Capital cost of } \\
\text { technology }(\mathrm{LE})\end{array}$ & $\begin{array}{l}\text { Selling } \\
\text { prices } \\
\text { per tonne }\end{array}$ & $\begin{array}{l}\text { Gross } \\
\text { Revenue } \\
\text { per tonne } \\
\text { bought in } \\
\text { (LE) }\end{array}$ & $\begin{array}{l}\text { Revenue } \\
\text { per tonne } \\
\text { bought in } \\
\quad \text { (LE) }\end{array}$ & $\begin{array}{l}\text { Net Value added } \\
\text { per tonne } \\
\text { bought in } \\
(\%)\end{array}$ \\
\hline $\begin{array}{l}\text { 1. After collection } \\
\text { /primary sorting }\end{array}$ & 1,500 & N/A & 1,500 & 1,500 & N/A & 0 & 1,500 & 1,500 & 1,500 & N/A \\
\hline $\begin{array}{l}\text { 2. After secondary } \\
\text { sorting/compaction }\end{array}$ & $\begin{array}{c}1,900 \\
(1,700)\end{array}$ & 2 & $\begin{array}{c}1,862 \\
(1,666)\end{array}$ & $\begin{array}{c}362 \\
(166)\end{array}$ & $\begin{array}{c}24 \\
(11)\end{array}$ & 0 & 1,700 & 1,666 & 166 & 11 \\
\hline 3. After shredding & $\begin{array}{c}2,500 \\
(2,200)\end{array}$ & 3 & $\begin{array}{c}2,425 \\
(2,134)\end{array}$ & $\begin{array}{c}525 \\
(434)\end{array}$ & $\begin{array}{c}28 \\
(26)\end{array}$ & 20,000 & 2,000 & 1,940 & 240 & 14 \\
\hline $\begin{array}{l}\text { 4. After washing / } \\
\text { drying }\end{array}$ & $\begin{array}{c}4,000 \\
(3,000)\end{array}$ & 5 & $\begin{array}{c}3,800 \\
(2,850)\end{array}$ & $\begin{array}{l}1,300 \\
(650)\end{array}$ & $\begin{array}{c}52 \\
(30)\end{array}$ & 50,000 & 3,300 & 3,135 & 1,195 & 57 \\
\hline $\begin{array}{l}\text { After secondary } \\
\text { sorting }+ \text { shredding }+ \\
\text { washing/drying }\end{array}$ & $\begin{array}{c}4,000 \\
(3,000)\end{array}$ & 10 & $\begin{array}{c}3,600 \\
(2,700)\end{array}$ & $\begin{array}{c}2,100 \\
(1,200)\end{array}$ & $\begin{array}{l}140 \\
(80)\end{array}$ & 70,000 & 3,300 & 2,970 & 1,470 & 98 \\
\hline After export tax & 5,600 & N/A & N/A & N/A & 40 & N/A & 4,500 & N/A & N/A & 35 \\
\hline
\end{tabular}

The prices shown are for the higher value transparent PET - the average selling price for shredded and washed coloured PET in 2015 is around LE 1,000/tonne lower. The figures in brackets reflect the seasonal variation in winter when the demand is the lowest. The final selling price (row 4) in June 2015 is around 700 LE/ tonne lower than prior to the oil price collapse in late 2014. June 2015 exchange rate: 1 US $\$=8$ LE.

Each row corresponds to one actor, and to one or more steps, in the value chain, the numbers corresponding to those for the actors in Figure 1. Separate columns show the selling price per output tonne following each step; the \% process loss at that step; the gross revenue per tonne of material entering the step (i.e. adjusting the selling price per output tonne for process losses at that step); the revenue added (i.e. the gross revenue less the price paid, i.e. the selling price from the previous step); and the $\%$ value added by that step (i.e. net revenue divided by the price paid (the selling price from the previous step)*100). The left side of the table presents our data from June 2015 ; while the right side provides the corresponding data gathered in June 2010 by Staffeld (2010). Process losses were estimated based on interviews and the type of equipment used; the more complex processes and those using more heat encounter higher losses. The additional column in the centre documents the capital cost of the equipment required for each processing step - this is for locally-made machines. The selling price by actor 1 (collectors / primary sorters) is taken as the 'baseline' from the rest of the table is calculated. For PET, the material is all sold out of the Zabaleen community after washing/ drying - for other plastics there may at least one additional value chain step (see Table 3 below).

All figures rounded to two significant figures. N/A - Not Applicable 
Waste collectors and primary sorters are the first actor in the value chain. Collection and primary sorting creates the material streams, to which other actors add value. The selling price of collectors/primary sorters is thus the 'baseline' from which the value added by subsequent steps is calculated. For PET, this baseline remained unchanged between 2010 and 2015, while the total value added to transparent PET by all the value chain steps within the Zabaleen community increased over the same period from $98 \%$ in 2010 to $140 \%$ in 2015 . The calculations for added value have taken into account estimated losses at each step of the value chain. The total value added is significantly reduced (by around $900 \mathrm{LE} / \mathrm{t}$, i.e. from $140 \%$ to $80 \%$ ) both in winter when market prices for recovered PET are lower, and also for coloured PET. The washing/drying step adds the most additional value, around $50 \%$ compared to around $25 \%$ for secondary sorting and for shredding. This reflects the capital costs of the equipment required: shredders are simple, cheap machines which are generally manufactured locally and cost 20,000 LE, while washing/drying equipment can cost up to 50,000 LE (\$1US= 8LE).

The last row in Table 2 reflects the 'value added' by the export tax, which clearly does not accrue to the recyclers. The tax rate is currently $40 \%$, which severely disadvantages the Zabaleen in a very competitive market.

Table 3 summarises the value added for each of the main types of recovered coloured plastics by each actor in the Zabaleen value chain, with corresponding values for the higher value white plastic (or transparent PET) shown in brackets. For conciseness, just two columns are provided for each type of plastic, showing the June 2015 selling price and the percentage value added. The selling prices, obtained by the collectors/ primary sorters for each type of plastic, is in a relatively narrow range, from LE $1,500-2,300 /$ t. After processing through the value chain, the final prices for materials leaving the Zabaleen community range from LE 3,000 - 7,000/t, with added values ranging from 75\%$135 \%$ for coloured plastics, and from $120 \%$ to over $200 \%$ for white/transparent plastics. The value added by a single actor (step) generally varies up to $30 \%$, but is higher for washing/drying of transparent PET (52\%) and for the combined steps of shredding and washing/drying of coloured LDPE, i.e. soft plastic bags (84\%). The last step of pelletizing adds a relatively consistent $10-20 \%$ in value.

Intermediate traders are present at any step in the process. They have revenues ranging from LE 250$1000 / t$ depending on the type of plastic and its colour. It is more profitable for other sellers and buyers to by-pass intermediate traders if they can do so, because they take a share of the overall value added. 
Table 3 - Net Value added for each of the main types of recovered coloured plastics at each step of the value chain within the Zabaleen community

\begin{tabular}{|c|c|c|c|c|c|c|c|c|c|}
\hline & $\begin{array}{c}\text { Process } \\
\text { Loss } \\
(\%)\end{array}$ & $\begin{array}{l}\text { PET } \\
\text { Selling } \\
\text { price } \\
(\text { LE/t) }\end{array}$ & $\begin{array}{c}\text { PET } \\
\text { Net } \\
\text { Value } \\
\text { added } \\
(\%)\end{array}$ & $\begin{array}{c}\text { LD-PE } \\
\text { Selling } \\
\text { price } \\
\text { (LE/t) }\end{array}$ & $\begin{array}{c}\text { LD-PE } \\
\text { Net } \\
\text { Value } \\
\text { added } \\
(\%)\end{array}$ & $\begin{array}{l}\text { HD-PE } \\
\text { Selling } \\
\text { Price } \\
\text { (LE/t) }\end{array}$ & $\begin{array}{c}\text { HD-PE } \\
\text { Net } \\
\text { Value } \\
\text { added } \\
(\%)\end{array}$ & $\begin{array}{c}\text { PP } \\
\text { Selling } \\
\text { price } \\
(\text { LE/t) }\end{array}$ & $\begin{array}{c}\text { PP Net } \\
\text { Value } \\
\text { added } \\
(\%)\end{array}$ \\
\hline $\begin{array}{l}\text { 1- After } \\
\text { collection / } \\
\text { primary } \\
\text { sorting }\end{array}$ & N/A & 1,500 & N/A & 1,700 & N/A & 2,300 & N/A & 2,300 & N/A \\
\hline $\begin{array}{l}\text { 2- After } \\
\text { secondary } \\
\text { sorting }\end{array}$ & 2 & $\begin{array}{c}1,700 \\
(1,900)\end{array}$ & $\begin{array}{c}11 \\
(24)\end{array}$ & $\begin{array}{c}2,000 \\
(3,000)\end{array}$ & $\begin{array}{c}15 \\
(73)\end{array}$ & $\begin{array}{c}2,700 \\
(3,100)\end{array}$ & $\begin{array}{c}15 \\
(32)\end{array}$ & $\begin{array}{c}3,000 \\
(3,500)\end{array}$ & $\begin{array}{c}28 \\
(49)\end{array}$ \\
\hline $\begin{array}{l}\text { 3- After } \\
\text { shredding }\end{array}$ & 3 & $\begin{array}{c}2,200 \\
(2,500)\end{array}$ & $\begin{array}{c}26 \\
(28)\end{array}$ & N/A & N/A & $\begin{array}{c}3,500 \\
(4,000)\end{array}$ & $\begin{array}{c}26 \\
(25)\end{array}$ & $\begin{array}{c}3,500 \\
(4,500)\end{array}$ & $\begin{array}{c}13 \\
(25)\end{array}$ \\
\hline $\begin{array}{l}\text { 4- After } \\
\text { washing / } \\
\text { drying }\end{array}$ & 5 & $\begin{array}{c}3,000 \\
(4,000)\end{array}$ & $\begin{array}{c}30 \\
(52)\end{array}$ & $\begin{array}{c}4,000 \\
(5,000)\end{array}$ & $\begin{array}{c}84 \\
(53)\end{array}$ & $\begin{array}{c}3,900 \\
(4,800)\end{array}$ & $\begin{array}{c}6 \\
(14)\end{array}$ & $\begin{array}{c}4,750 \\
(5,700)\end{array}$ & $\begin{array}{l}29 \\
(20)\end{array}$ \\
\hline $\begin{array}{l}\text { 5- After } \\
\text { pelletizing }\end{array}$ & 10 & N/A & N/A & $\begin{array}{c}5,000 \\
(6,500)\end{array}$ & $\begin{array}{l}13 \\
17\end{array}$ & $\begin{array}{c}5,000 \\
(6,400)\end{array}$ & $\begin{array}{c}15 \\
(20)\end{array}$ & $\begin{array}{c}6,000 \\
(7,000)\end{array}$ & $\begin{array}{c}14 \\
(11)\end{array}$ \\
\hline $\begin{array}{l}\text { Total within } \\
\text { the Zabaleen } \\
\text { community }\end{array}$ & $\begin{array}{c}20 \\
\text { (10 for } \\
\text { PET) }\end{array}$ & - & $\begin{array}{c}80 \\
(140)\end{array}$ & & $\begin{array}{c}135 \\
(206)\end{array}$ & & $\begin{array}{c}74 \\
(123)\end{array}$ & & $\begin{array}{c}109 \\
(143)\end{array}$ \\
\hline
\end{tabular}

The data in brackets is for the higher value white plastics, or in the case of PET, transparent PET. For LD-PE, the material is shredded and washed in a single process called 'washing line', so the data for step 3 is shown as N/A (Not Applicable). PET is not pelletized by the Zabaleen, so step 5 is shown as N/A. PET is the main plastic that is exported outside Egypt, so the impact of export tax (see Table 2) is not shown here. Process losses for each step as estimated in Table 2 are assumed to be the same for each type of plastic (except that pelletization, with an estimated loss of $10 \%$, is not applied to PET); these losses have been taken into account at each step to calculate the net value added per tonne of material bought into that step. 1 US\$ $=8 \mathrm{LE}$.

N/A - Not applicable

Table 4 shows an indicative calculation of the relative contribution to overall revenue of the collectors/ primary sorters (actor 1 in the value chain) from recycling each component in the waste stream. This is calculated from an 'average' waste composition for Egypt as a whole (Zaki et al., 2013) - in practice this will vary widely depending inter alia on the socio-economic characteristics of the neighbourhood from which the waste is collected. Of an estimated maximum potential revenue from recycling of 255270 LE per tonne of waste collected, around $70 \%$ comes from recycling plastics, although these only comprise $13 \%$ by weight of the mixed waste. The next most important contributions come from paper/cardboard, glass and aluminium cans (each around 8\%).

Table 4 excludes any income from the organic waste fraction. This was a major element of the Zabaleen economy in the past, as each family kept pigs which fed on the organic fraction separated from the mixed waste, with the fertilised residues going to a composting plant. In 2009, the Egyptian government reacted to the international swine flu epidemic by banning and culling pigs. Official slaughter houses are now operating again, but the government is trying to relocate pig-rearing outside the urban areas; this practice is now relatively small-scale. 
Table 4 - Indicative calculation of the relative contribution to overall earnings of the collectors/ primary sorters (actor 1 in the value chain) which comes from recycling each individual component in the waste stream

\begin{tabular}{|c|c|c|c|c|c|c|c|c|c|c|}
\hline & 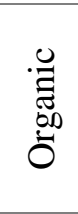 & $\frac{\underbrace{n}_{\tilde{E}}}{\frac{\tilde{E}}{2}}$ & 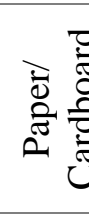 & $\begin{array}{l}\infty \\
\frac{0}{0} \\
\frac{\tilde{O}}{0}\end{array}$ & 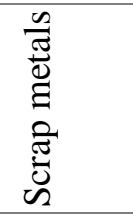 & 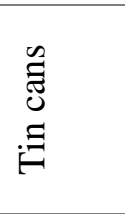 & 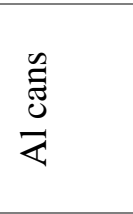 & $\frac{\tilde{\Xi}}{\stackrel{\Xi}{0}}$ & $\stackrel{1}{2}$ & 空 \\
\hline Composition of MSW (\%) & 56 & 13 & 10 & 4 & $0.8-0.9$ & $0.8-0.9$ & $0.2-0.4$ & 15 & N/A & 100 \\
\hline $\begin{array}{l}\text { Maximum Separation } \\
\text { (\% of total) }\end{array}$ & 90 & 80 & 80 & 100 & 100 & 100 & 100 & 67 & N/A & N/A \\
\hline Separated MSW (\%) & 50 & 10 & 8 & 4 & $0.8-0.9$ & $0.8-0.9$ & $0.2-0.4$ & 10 & 15 & 100 \\
\hline $\begin{array}{l}\text { Collector mean revenue } \\
\text { (LE/tonne) }\end{array}$ & - & 1800 & 300 & 500 & 1000 & 300 & 7000 & 0 & 50 & N/A \\
\hline $\begin{array}{l}\text { Revenue per tonne of } \\
\text { mixed waste }(L E)\end{array}$ & - & 180 & 24 & 20 & $8-9$ & $2.4-2.7$ & $14-28$ & N/A & 7.5 & $\begin{array}{l}255 \\
270\end{array}$ \\
\hline Revenue distribution (\%) & - & $\begin{array}{c}67- \\
71\end{array}$ & 9 & 8 & 3 & 1 & $6-10$ & N/A & 3 & 100 \\
\hline
\end{tabular}

The first row shows the approximate composition of the mixed waste collected from households, estimated by Zaki et al. (2013) as an average for Egypt - in practice there will be considerable variation between cities and neighbourhoods within cities. The second row shows the hypothetical maximum \% of each waste stream which could potentially be separated and processed further; in practice, actual separation rates are likely to be less than these maximum figures, so the total revenue calculated here is an upper limit - the main purpose is rather to show the likely relative contributions to overall earning of each material. In the second row, it is assumed that $10 \%$ of the organic fraction is high calorific value fibrous material that could be separated into a sellable refuse derived fuel (RDF) fraction which is further processed for sale to the cement industry (RDF has been added as an additional column, shown in italics). Similarly, it is assumed that $80 \%$ of both paper and plastics could be separated for direct recycling, while the balance can be separated into the RDF fraction; also, one third of the unclassified 'Others' fraction of MSW (which includes textiles) can be separated as RDF. The third row indicates the final fractions of separated waste available for processing. The fourth row shows average selling price obtained by actor 1 , the collectors/ primary sorters, for that material, taken from the value added tables compiled in this study (June 2015). Income from organic wastes is not included, as the keeping of pigs is no longer legal. For plastics, there are no available data on the relative proportions of the four main plastic types, although anecdotally PET is the largest; the average price shown here is an estimate based on the price data in Table 3. 1 US\$ $=8$ LE.

Key: Al - Aluminium; RDF - Refused Derived Fuel; LE - Egyptian pound

The overall income of collectors/sorters comes from three main sources: any direct payment for collecting the waste; revenues from separating recyclable materials; and any supplementary income from keeping pigs or other livestock which can feed on the organic fraction. The income from collection is often routed via intermediaries, so that coming to the actual collectors is relatively low. This means that of the three sources, the income from recycling is the most significant. Table 4 suggests a maximum potential recycling income of LE 255-270/t, so for a family collecting one or two loads per day, equivalent to about 2 tonnes a day, the gross daily income before expenses could theoretically be up to LE 500. Expenses to be deducted include vehicle and fuel costs, both for collection and transport of residual wastes to the final disposal site. Our interviews suggest that average daily incomes are LE 30-50 per person per day, which for a family of six is equivalent to LE 180-300 per day. 
At the downstream end of the value chain the actors normally specialise in one material stream, so the revenues per tonne of material processed are actual revenues. These are shown in Table 5 for the last actor in each value chain (e.g. for PET, this is actor 4 carrying out washing/drying; and for other plastics, actor 5 carrying out pelletization). Workshop owners were reluctant to disclose their overall turnover or profit, but from the data on revenue per tonne and estimates of the daily throughput of different types of workshop, the total revenue (value added) can be estimated. For example, consider a medium pelletizing enterprise for hard plastics such as PP or HD-PE with a daily production capacity of 5 tonnes and a storage capacity of 100 tonnes. Table 5 shows a typical revenue of perhaps LE 650/t, which equates to LE 3,300 per day or about LE 1 million per year. Profit margins are not known, but the estimated annual revenue does put the capital costs of a modern, imported extruder/pelletizer (LE 250,000) into context.

Interviews suggest that the average income for a worker in plastics recycling varies between LE 70/day for a young employee to LE 90/day for an experienced worker. This is higher than for waste collectors and primary sorters, some of whom supplement their income by working part-time in recycling workshops.

Table 5 - Potential revenues of the last actor in the value chain for each material stream

\begin{tabular}{|c|c|c|c|c|c|c|c|c|}
\hline $\begin{array}{c}\text { Material } \\
\text { stream }\end{array}$ & Organic & $\begin{array}{c}\text { Paper/ } \\
\text { Cardboard }\end{array}$ & Glass & $\begin{array}{l}\text { Scrap } \\
\text { metal }\end{array}$ & Tin cans & Aluminium & RDF & \\
\hline $\begin{array}{l}\text { Actual } \\
\text { revenues of the } \\
\text { last actor }(\mathrm{LE} / \mathrm{t})\end{array}$ & - & 300 & 300 & 400 & 150 & 1750 & 175 & \\
\hline Plastic Type & \multicolumn{2}{|c|}{ PET } & \multicolumn{2}{|c|}{ LD-PE } & \multicolumn{2}{|c|}{ HD-PE } & \multicolumn{2}{|c|}{$\mathbf{P P}$} \\
\hline & Coloured & Transparent & Coloured & White & Coloured & White & Coloured & White \\
\hline $\begin{array}{l}\text { Net revenues } \\
\text { of the last actor } \\
(\mathrm{LE} / \mathrm{t})\end{array}$ & 650 & 1,300 & 500 & 850 & 600 & 960 & 650 & 600 \\
\hline
\end{tabular}

For comparative purposes the revenues from organic waste are not included because pig ownership is usually upstream in the value chain. Plastics are shown separately, with data provided for four plastic types, distinguishing for each between white/ transparent and coloured plastics. Process losses as shown in Tables 2 and 3 have been taken into account (totaling 10\% for PET and 20\% (including 10\% losses during pelletization) for the other types of plastic). All data shown as LE per tonne of material purchased by the last actor in the value chain.

$1 \mathrm{US} \$=8$ LE.RDF - refuse derived fuel 


\subsection{Stage 3 - Indicator set for value chain development (Barriers and Constraints)}

Based partly on the literature and partly on observations during the field study of the Zabaleen, a set of specific indicators within each of the three categories are set out in Table 6. The indicators are intended to be used to identify both the technical and the socio-economic challenges which need to be addressed in order to develop the value chain. The use of the indicator set is illustrated here by identifying the barriers and constraints which need to be addressed in further developing the value chain of the Zabaleen.

\subsubsection{Connections}

\section{a) Economic information transfer}

Information sharing within the Zabaleen value chains is mostly about volumes and buying prices, not about market prices and fluctuations. Upstream actors lack education which does not help information transfer. Value chain actors downstream rarely pass on market price increases to those upstream; for example, Table 2 shows that the market price for shredded and washed PET increased by $20 \%$ between June 2010 and June 2015, but the selling price of the collectors/primary sorters did not change.

\section{b) Technical Knowledge}

The level of technical understanding and expertise is relatively low at the upstream end of the value chain. The prices paid to the last value chain actor by the recycling factory depends critically on the quality of the material. Material trades are partially made on credit; recycling factories often pay only $50 \%$ of the buying price at delivery, with the balance being paid after the material undergoes quality control checks. Payments can be discounted if the quality standards are not met. It is thus crucial that each actor in the chain knows the quality standard required and how their actions impact on this.

\section{c) Balance of power}

There is a partial asymmetry of powers and incentives across the value chain. Collectors may work under the supervision of intermediaries for setting the khot (collection route) and collecting household fees. They do not get a lot out of income from the collection service provided - revenues from recycling are generally greater.

Similarly, the balance of power within the recycling value chain rests with the larger downstream recyclers. Those upstream are relatively poorly educated, handle smaller volumes of recyclable materials and have limited storage capacity.

However, this is an issue even for those downstream in the Zabaleen value chain, who can be at a significant disadvantage in their dealings with the formal recycling industry, particularly where they need to export materials. The Zabaleen rely on prices set by the formal private companies, who in turn rely on (often international) markets. 
Table 6 - Indicator set for value chain development

\begin{tabular}{l} 
1. Connections \\
\hline a) Economic information transfer \\
Access to economic information such \\
as current market prices and price \\
fluctuations. This is crucial to reach \\
collaborative agreements.
\end{tabular}

\section{b) Technical knowledge}

The level of understanding of quality standards and the actions required to achieve such standards.

\section{c) Balance of power}

Relative level of power between upstream and downstream actors within the value chain, and between the value chain actors and their external trading partners

\section{d) Horizontal Cooperation}

The relationship between different enterprises acting within the same step of the value chain, in terms of information exchange, investment capabilities and skills coordination. Cooperation as a group also fosters negotiating power.

\section{e) Diversity of business partners}

The range of partners determines the extent of the network and the potential for a value chain actor to expand their business.

\section{f) Resilience to shocks}

Ability of actors at a particular step in the value chain step to survive fluctuations in market demand and prices and to cope with more stringent environmental and quality standards.

\section{Waste Valorisation}

a) Quality of Material

The level of waste valorisation and the range of outlet markets depend on

\section{b) Material Supply}

The amount of material gathered by the collectors and the actions required to optimize the distribution of the material within the community

\section{c) Net revenues}

The net revenues of each actor in the value chain need to be positive, with sales revenues covering the capital and operating costs. the quality of material.

\section{Enabling Environment}

\section{a) Land security}

Security of land tenure brings stability to the value chain and allows the actors to provide security for financial loans and thus to invest in their businesses.

\section{b) Business registration}

Integration of the informal sector requires a system to facilitate and encourage registration and recognition as legal and tax paying businesses. This is an important step in extending the environmental and health \& safety control regimes.

\section{c) Access to finance}

Access to finance for working capital needs or for investment. This could be direct funding through grants or other subsidies, or access to loans from banks or micro-financing. It could also include contributions from product producers under extended producer responsibility (EPR).

\section{d) Production capacity}

The quantity of material which can be valorised in a limited period of time. It depends both on the technical constraints and on social constraints imposed by traditions and working conditions.

\section{e) Competitiveness}

The ability of a particular value chain to compete on local and international markets.

\section{f) Value Chain completeness}

Waste valorisation within a particular value chain is more complete the nearer it gets to the manufacturing of high-value final products.

\section{d) Business skills}

Facilitates contract negotiations with local authorities, other value chain actors, the recycling companies and product producers.

\section{e) Source Segregation}

Separation of waste by the waste generator enhances material quality by separating wet organics from dry recyclables, and by eliminating cross-contamination.

\section{f) Optimised waste collection}

An organised collection system where the material is collected at regular intervals and payments are made directly to the collection business.

'Connections' represent the linkages between waste generators, collectors, sorters, middlemen, recyclers and/or traders and with the recycling industry. 'Waste Valorisation' includes indicators impacting the value added by recycling at different steps and by different actors of the informal recycling value chain. 'Enabling Environment' focuses on the broader sectorial and policy contexts. 


\section{d) Horizontal Cooperation}

Cooperation among those acting within the same step in the value chain is important. A major focus in the literature is on the need for organisation and co-operation between individual recyclers or enterprises, e.g. through co-operatives, to provide a united voice in negotiations with the authorities or those either upstream or downstream in the value chain, and also to improve access to training, skills and finance for working capital or for investment. A general lack of cooperation was observed among the Zabaleen businesses operating at the same value chain step. The most vulnerable steps are collectors/primary sorters and enterprises specialising in secondary sorting, but they rarely cooperate or let other enterprises enter the family business.

\section{e) Diversity of business partners}

It is beneficial for value chain actors to have access to a wide range of potential business partners, rather than being forced to rely on just one buyer or one type of buyer. This is a particular constraint for primary collectors/sorters and secondary sorters, who through a lack of storage capacity are often forced to sell small quantities of material to an intermediate trader, rather being able to deal directly with other workshops. However, the downstream recyclers would also benefit if they could have access to a diversity of potential buyers in the external recycling industry, either in Egypt and/or internationally.

\section{f) Resilience to shocks}

Recycling value chains operate in a difficult trading situation. They are vulnerable to quite severe fluctuations in raw material prices and in market demand - despite contractual agreements with the recycling industry, it is not uncommon for the quantities bought to fluctuate by an order of magnitude. Increasingly stringent environmental and material quality standards and the behaviour of competitors can also be an issue. Again, it is the upstream actors who are the least resilient to shocks.

An example is provided by the impact of the collapse in the oil price, which fell by around $50 \%$ in the 6-9 months period before our field work in June 2015. This reduced the price of virgin plastics to the same level as recycled materials so that the price of secondary raw PET after washing had by June 2015 stabilised at LE 700/t below earlier levels in order to remain competitive, and demand was also lower. During this period of market turbulence, which coincided with seasonally low winter prices for secondary PET, those value chain actors who had the most storage capacity were affected least, as they could stockpile rather than sell when prices were at their lowest. In contrast, some of the smaller upstream actors lost $40-45 \%$ of their revenues at the lowest point. It is unclear how resilient the value chain will be in response to subsequent market volatility, and the apparent likely halving again of oil prices at the time of writing (end of 2015). 


\subsubsection{Waste Valorisation}

\section{a) Quality of material}

The entire value chain revenues depend on the accuracy of sorting, and the resulting level of cleanliness and contamination of the material. The Zabaleen have limited theoretical knowledge of the classification of plastic polymers. Manual sorting by colour is the primary focus, for which empirical methods are often used; the process is slow and limits the marketability of secondary raw materials. Outlet markets for coloured materials are limited, particularly when the demand is seasonal; the material has to be stored or sold at unprofitable prices.

\section{b) Material supply}

Two related issues are access by each value chain actor to their raw materials and the adequacy of record keeping. The whole value chain relies on access to the original waste streams by the collectors, which has been a contentious issue following the introduction of private sector waste collectors who have been effectively competing with the Zabaleen since 2002. In addition, clear records of waste inputs to, and material flows through, the Zabaleen value chain are not available. Some collectors weigh the waste on a mechanical balance but this is not currently standard practice.

\section{c) Net revenues}

This indicator focuses on the viability of each actor in the value chain. Are the net revenues positive, so that the revenues cover the capital and operating costs? Our survey suggests that current market prices for locally made products such as hangers are not always sufficient to cover the production costs. Small workshops upstream in the value chain, including primary and secondary sorting, have relatively low margins of profitability (Table 3), while being very labour intensive. Even washing/drying of plastics, which can have relatively higher revenues, also have low profit margins due to a combination of being both labour intensive and a high consumer of both water and electricity (e.g. a workshop processing 2 tonnes/day of LD-PE consumes $\sim$ LE 10,000 worth of each per month, representing a cost of $\sim$ LE 400 per tonne). The result is that many, particularly the smaller, sorting and washing enterprises rely on low labour, water and electricity costs to remain profitable - so both child labour and illegal connections to utilities remain real issues.

\section{d) Production capacity}

This indicator seeks to identify those issues which constrain the overall throughput of the value chain. One problem is the allocation of collection sectors by the authorities, which is by number of households; if this does not account for unregistered buildings, the collectors cannot cope with the volume of waste. Downstream, a particular technical constraint is the limited capacity of the shredding machines or washing lines, which is commonly 1-2 tonnes per day. 


\section{e) Competitiveness}

The competitiveness of the Zabaleen in local and international markets is constrained both by a lack of market access and product quality. The biggest markets are often international, but access is constrained both by high export taxes, poor market awareness and higher quality standards, which constrains the export of valuable materials such as transparent PET.

\section{f) Value chain completeness}

The focus here is on producing as high-value and as near final product as possible. The Zabaleen value chains compare favourably to those operated by most other informal sector recyclers around the world, in that they include a number of steps adding value to the raw material (Wilson et al., 2006; Gerdes and Gunsilius, 2010; Scheinberg and Savain, 2015). However, the main focus is still on trading secondary raw materials rather than on manufacturing or marketing final products. There are some exceptions where the Zabaleen operate complete value chains, often for low-value products such as plastic hangers, floor mats and shoe soles. In addition, an NGO runs product manufacturing training as part of an educational initiative for girls, making for example artisanal hand-made paper and highvalue craft products.

\subsubsection{Enabling Environment}

\section{a) Land security}

Insecurity concerning land ownership is a major barrier to further value chain development. Historically, people living in the largest Zabaleen settlement in Mokattam started to sell land on an informal basis during the 1980s, through an urban upgrading project implemented by a private firm and an NGO working for improved living conditions in the settlement (CID, 2001). Other official endeavours were made in 2000-2006 to enable the residents to buy their land for average prices but were only partially successful. However, the residents have established informal ownership to the land in the settlement, especially after the 2011 revolution when some took the chance of instability at that time to sell, buy, and even construct informally multi-storey buildings. Nevertheless, lack of official documents still affect negatively on having proper collateral in order to get loans from banks.

A related issue is that the settlements at Mokattam and Menshiet Nasser have now been designated as residential-only areas, so both the Zabaleen workshops and the keeping of pigs are not allowed. The authorities have been working for a number of years to relocate Zabaleen businesses to new recycling zones in the desert outside Cairo, but this has been resisted by many in the communities because of the distance to the their collection rounds within the city.

The land security situation has been easier in some other Zabaleen settlements, such as Ezbet El Nakhl, where the land was not government owned, so the community managed to buy it gradually from the original owners. 


\section{b) Business registration}

An important aspect of integration of the informal sector is their registration as legal and tax-paying businesses under national legislation, which importantly also brings them within environmental and health and safety control regimes. Facilitating this has been a major focus in some countries such as Brazil (Gerdes and Gunsilius, 2010; Campos, 2014). Our interviews with the Zabaleen suggest a perception that the current Egyptian system is loaded against them. There is a lack of transparency in tax calculations, so the authorities are seen to decide arbitrarily on the amount of tax, and to ask for unreasonable payments before registering an enterprise. In addition, some Zabaleen settlements have been designated as 'residential only', so there is a perception that, in order to register businesses, it would be necessary to accept relocation to new recycling zones outside the city, which would increase collection and transportation costs. The result is that some Zabaleen 'prefer' to remain informal.

\section{c) Access to finance}

Access to finance for working capital and for investment is a key requirement for value chain development. The banks will not issue loans to informal businesses and workers. Sources of microfinance are often inadequate. For example, LE 3,000 loans were given by an NGO called the Evangelical Association for Development. This amount was not sufficient to invest in new machines or greater storage space, so tended to be used instead on salaries or other operating costs, rather than on upgrading the recycling value chain.

Mention should also be made of the potential for extended producer responsibility (EPR) in providing an additional income source for informal sector recycling. The concept has been pioneered in Europe, in order to transfer the responsibility (and the costs) of managing products which enter the municipal waste stream at the end of their life from local authorities back to the producers of those products (Cahill et al., 2011). There is much current interest in extending EPR also to developing countries (Rodic et al., 2015; Agrawal et al., 2015), including current work in Egypt to develop mechanisms and draft legislation. One example of an existing, on-going voluntary initiative is in Mokattam, where an NGO runs a 'learning and earning' school for Zabaleen boys. This was designed and set up by CID in 2001 as a social enterprise, originally funded by UNESCO but now sustainably financed by Proctor and Gamble as part of their corporate social responsibility (CSR) programme. Proctor and Gamble are concerned at their used shampoo bottles being refilled and sold as counterfeit products; so they pay older Zabaleen boys to buy the bottles from the collectors, to shred them in the school's shredder and to submit detailed records of how many of each type of bottle. This both provides the boys' family with an income and requires the boys to be able to read, write and count and to continue to attend the school. The school sells the shredded plastic back to workshops, using the income to pay the teachers and to educate the younger boys so that they too can begin to earn an income to support their continuing education (Shaker, 2014b). 


\section{d) Business skills}

All of the Zabaleen value chain actors acknowledge that they are lacking some business and entrepreneurial skills, including those for negotiation of contracts with the authorities or collection companies, others in the value chain, recycling companies and indeed product producers. But they also can be sceptical about new knowledge as they have great experience in recycling.

\section{e) Source segregation}

It is a general principle of recycling in high-income countries that the waste is separated at source by the waste generator, in particular segregating (wet) organic materials from dry recyclables. This immediately reduces health and safety concerns and dirty working conditions for the recyclers, and enhances the quality of all the recycled materials along the value chain. Indeed, most quality standards world-wide for compost and other products from organic wastes require that the input material has been separated at source (UNEP, 2015).

Waste segregation is currently not implemented by the responsible authorities in Egypt. Poor knowledge of waste management practices by residents, a lack of incentives to segregate wastes and the lack of equipment to collect segregated wastes hinder the development of source separation programmes.

\section{f) Optimised waste collection}

There is no correct assessment of the physical/technical capacities of the Zabaleen for waste collection. When the waste management system was privatised in 2002, private companies hired the Zabaleen as labourers not as entrepreneurs. The revenues of collectors are lower when a contractor allocates the collection area, especially in poor districts, because household fees are lower and the quantities of dry recyclables are reduced. As a result, some collectors prefer to be contracted in nearby Governorates such as Fayoum Governorate or Al Gharbia because they can sign direct contracts with the local councils.

\subsection{Stage 4 - System Dynamic Map}

This stage maps the connections between the indicators and their influence on both the stocks at each step in the value chain and the flow variables (which represent the rate of change e.g. the sorting rate or recycling rate). The connections were identified both from the general indicator descriptions in Table 6 and also from the application of the indicators to analyse the barriers and constraints to value chain development among the Zabaleen. Figure 2 presents the resulting System Dynamic Map showing, through the connections between the indicators, the stocks and the flow variables, how much influence each indicator has. 
The System Dynamic Map is a generic tool, but the connections may vary and should be verified using specific local information. For our example of the Zabaleen, the connections were validated by crosschecking the information provided by the various stakeholders. A wide range of interviews were conducted and observations made during numerous site visits, so we believe that the connections shown in Figure 2 are robust. These connections are specific to the Zabaleen, but this version of the System Dynamic Map can provide initial guidance to other informal recycling communities as they seek to develop their value chains.

The more highly connected the indicator, the greater impact it has on the overall system. To take source segregation as an example, this impacts the production capacity because it is easier to sort and process materials when they have been segregated at source. It also impacts on two of the flow variables, the sorting rate and the recycling rate. Source segregation also impacts on the quality of material because it prevents cross-contamination between wet organics and dry recyclables. Finally it impacts on the level of horizontal cooperation, because establishing a plan to promote source segregation requires value chain actors, notably collectors, to work closely together to educate householders and modify how the waste is transported.

Figure 2 allows identification of the indicators with the greatest impact on the development of the value chain because these impact on the largest number of other indicators, stocks and flow variables. For the Zabaleen, these are source segregation, optimised waste collection, access to finance and technical knowledge. The first three of these has five connections (arrows pointing to other variables), while the last has four connections out plus two more in, compared to a maximum of just two connections out for any other indicator. Other indicators both influence and are influenced by others examples with four such inter-connections are value chain completeness and resilience to shocks (each with two connections in and two out) and production capacity (three connections in and one out). 


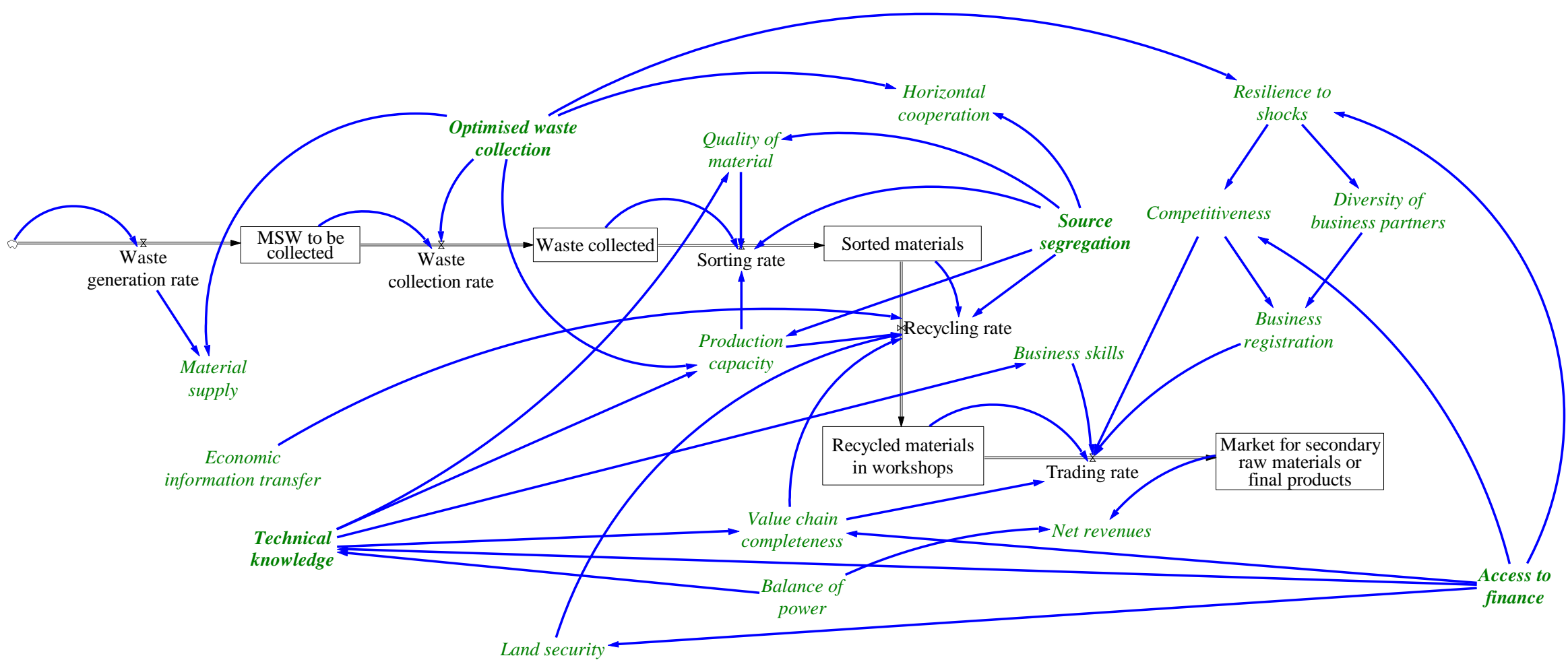

\section{Figure 2 - System Dynamic Map}

This tool maps the connections between the indicators and their influence on both the stocks at each step in the value chain and on the flow variables. The stocks (symbolised by rectangles) represent the accumulation of waste or recyclables in the system, while the flow variables (symbolised by valves) represent the rate of change in stocks. The map was created using Vensim ${ }^{\circledR}$. The eighteen indicators for value chain development (Table 6) are depicted in italics and green. The bold blue arrows show how each indicator influences both other indicators, the stocks and the flow variables. The more arrows that 'leave' from one indicator (i.e. the more 'connected' it is), the more influence that indicator has. The more arrows that 'come in' to one variable, the more actions are required to change (upgrade) that variable. The four most connected indicators are shown in bold and italics: these are optimised waste collection, source segregation, access to finance and technical knowledge. Each of these has five connections (arrows pointing to other variables), compared to a maximum of just two for any other indicators. The System Dynamic Map is a generic tool, but the connections may vary and should be verified using specific local information. The connections shown in Figure 2 are specific to the Zabaleen, but this version of the System Dynamic Map can provide initial guidance to other informal recycling communities as they seek to develop their value chains. 


\section{CONCLUSIONS}

A methodology for applying value chain analysis has been developed for use with the informal waste recycling sector, providing a four-stage VCA toolkit. Stage 1 maps the value chain. Stage 2 tabulates the value added at each step in the value chain. Stage 3 provides a set of indicators for use in value chain development in order to address the technical and socio-economic challenges facing informal sector recyclers. Stage 4 has developed a novel system dynamic map to show connections between the indicators and with the stocks and flow variables in the value chain.

The development and the demonstration of the component VCA methods are inextricably linked. Informal sector recycling value chains are very well established for the Zabaleen in Cairo and the markets for most recyclables are mature. We have therefore used this case to both develop and demonstrate the VCA toolkit.

Stage 1 mapping of the value chain for the specific case of PET bottles highlights a number of constraints faced by the Zabaleen. The value chain begins upstream with the collectors and primary sorters, moving through various intermediate trading and processing steps towards the recyclers who are downstream. The reliance on manual sorting upstream to recognise and separate different polymers, and contamination of the bottles by collars and caps, results in a transparent PET product unlikely to meet international quality standards. Upstream actors often lack sufficient storage space to accumulate material, so that intermediate traders and larger workshops/recyclers have an advantage.

The overall income of Zabaleen collectors/primary sorters, the first actor in the value chain, comes from direct payment for collecting the waste; revenues from separating recyclable materials; and any supplementary income from keeping pigs or other livestock which can feed on the organic fraction. Since the cull and ban on pigs in 2009 , the dry recycling revenue stream has been dominant. The stage 2 analysis of revenues at each step in the value chain shows clearly the advantage of integrating value added steps within the Zabaleen community, rather than selling the primary sorted materials directly to external dealers as is common practice in many countries. Plastics contribute up to $70 \%$ of recycling revenues; depending on the polymer type, the colour and the degree of processing, total value added by the Zabaleen ranges from $75 \%$ to more than $200 \%$. In general, the enterprises operating downstream generate more revenue and are less vulnerable to market fluctuations. For example, the selling price obtained by the upstream collectors/primary sorters for PET bottles did not change from 2010 to 2015 , while the market price obtained by the downstream recyclers increased by $20 \%$. Similarly, when market prices crashed following the oil price collapse in late 2014, it was the upstream actors, who lack storage space and had to sell even when prices were at their lowest, who were hit hardest.

For stage 3, the indicators proposed are in three categories: connections in the value chain, waste valorisation and the enabling environment. Six indicators have been identified and defined within each 
category. The indicators have been demonstrated through an analysis of the value chain development needs of the Zabaleen.

The results of the indicator analysis feed into Stage 4, which uses a systems dynamic map to identify the most highly connected indicators, which influence the highest number of other indicators, stocks and flow variables, where interventions are likely to have the greatest impact on the overall value chain. The four indicators where intervention has the greatest potential to improve the Zabaleen value chain for both the upstream and downstream actors are: source segregation to improve the quality of the recyclable materials entering into the value chain; optimising access to waste; and improving both access to finance and technical knowledge.

Value chain analysis provides a significant and powerful addition to the analytical tools available for improving the position of the informal recycling sector. The global value of the four-stage toolkit developed and demonstrated here is that it provides a robust and sequential methodology to analyse complex informal recycling sectors such as the Zabaleen. The system dynamics map is the final visual output, which helps to target the need for interventions in a specific local situation. It provides the confidence that such targeted interventions will have the greatest impact on the overall system. This new toolkit complements existing approaches such as the InteRa framework and tool for use in designing interventions (Velis et al., 2012) and the recycling framework tool to visualise and analyse inclusive (both formal and informal) recycling performance (Scheinberg and Simpson, 2015). Indeed, the recommendations of Velis et al., (2012) strongly reinforce our identification, based on the Zabaleen case study, of the critical areas for potential intervention to strengthen and integrate the informal recycling sector.

\section{Acknowledgements}

This research would not have been possible without the help of those who provided assistance and data including staff of GIZ, informal workers, NGOs especially Ezzat Naem Gendy, director of the Spirit of Youth Association, and other solid waste management professionals in Egypt. We are also grateful to Dr Sanjay Gupta for sharing with us his unpublished work on the use of VCA in the solid waste recycling sector in India. Financial support for RJ's field visit Cairo was provided by Deutsche Gesellschaft für Internationale, Zusammenarbeit GmbH (GIZ).

\section{Declaration of conflicting interests}

The authors declare no potential conflicts of interest with respect to the research, authorship and/or publication of this article. 


\section{References}

Agrawal, S., Singh, R.K., Murtaza, Q., 2015. A literature review and perspectives in reverse logistics. Resources, Conservation and Recycling, 97, 76-92.

Ahmed, S.A., Ali, M., 2004. Partnerships for solid waste management in developing countries: linking theories to realities. Habitat International, 28 (3), 467-479.

Bagadayeva, D., 2009. The value chain analysis of plastic waste recycling in Delhi, India. MSc Thesis, Imperial College London.

Bowman J., Dettmann M., Hillyard J., Osberg M., Wollschlager L., 2011. The Waste Management Analysis Tool and User Manual: A Tool for Financial and Social Cost-Benefit Analysis of Informal Waste Management. MPP Professional Paper, University of Minnesota. [Online]. http://conservancy.umn.edu/bitstream/handle/11299/107535/Bowman_The\%20Waste\%20Managemen t\%20Analysis\%20Tool.pdf? sequence $=1$. (Accessed $1^{\text {st }}$ February).

Cahill, R., Grimes, S.M., Wilson, D.C., 2011. Extended producer responsibility for packaging wastes and WEEE - a comparison of implementation and the role of local authorities across Europe. Waste Management \& Research, 29(5) 455-479.

Campos, H.K.T., 2014. Recycling in Brazil: Challenges and prospects. Resources, Conservation and Recycling 85, 130-138.

C.I.D. Consulting Group, 2001. The Informal Solid Waste Sector in Egypt: Prospects for Formalization. A study supported by Ford Foundation.

C.I.D. Consulting Group, 2008. The informal sector in waste recycling in Egypt. Report for GIZ, May 2008, pp. 54. [Online]. http://www.middleeastpdx.org/resources/wp-content/uploads/2013/03/THEINFORMAL-SECTOR-IN-WASTE-RECYCLING-IN-EGYPT2.pdf (Accessed 1 February, 2016).

Chang, N., Pires, A., Martinho, G., 2011. Empowering systems analysis for solid waste management: challenges, trends, and perspectives. Critical Reviews in Environmental Science and Technology, 41 (16), 1449-1530.

CHF International, 2012. Value Chain Case Study Development of a Public Sector Value Chain: Solid Waste Management. Global Communities. [Online] . http://www.globalcommunities.org/publications/2012-ghana-waste-mgmt.pdf (Accessed $1^{\text {st }}$ February 2016).

Cohen, P., IJgosse, J. and Sturzenegger, G. (2013) Preparing Informal Recycler Inclusion Plans: An Operational Guide. Washington: Inter-American Development Bank. [Online] https://publications.iadb.org/handle/11319/697 (Accessed 10 March 2016)

Conrad, F., Joos, V., 2010. Mokattam: World's Largest Recycling Hub. [Online]. http://www.studiobasel.com/assets/files/files/04_Mokattam_web.pdf, pp111-160 (Accessed on $18^{\text {th }}$ May 2015).

Didero, M., 2012. Cairo's Informal Waste Collectors: A Multi-scale and Conflict Sensitive Perspective on Sustainable Livelihoods. Erdkunde, 66, 27-44.

Ezeah, C., Fazakerley, J.A., Roberts, C.L., 2013. Emerging trends in informal sector recycling in developing and transition countries. Waste Management, 33, 2509-2519.

Fahmi, W. S., 2005. The impact of privatization of solid waste management on the Zabaleen garbage collectors of Cairo. Environment and Urbanization, 17 (2), 155-170.

Fahmi, W., Sutton K., 2006. Cairo's Zabaleen garbage recyclers: Multi-nationals' takeover and state relocation plans. Habitat International, 30 (4) 809-837.

Fahmi, W., Sutton, K., 2010. Cairo's contested garbage: Sustainable Solid waste Management and the Zabaleen's right to the City. Sustainability, 2 (6), 1765-1783.

Gerdes, P., Gunsilius, E., 2010. The waste experts: enabling conditions for informal sector integration in solid waste management. Lessons learned from Brazil, Egypt and India. Eschborn: GTZ. [Online]: 
https://www.giz.de/en/downloads/gtz2010-waste-experts-conditions-is-integration.pdf (Accessed 1 February, 2016).

GIZ, 2015. National Solid Waste Management Programme (NSWMP) in Egypt. Project description. [Online] https://www.giz.de/en/worldwide/22230.html (Accessed $1^{\text {st }}$ February 2016).

Gunsilius, E., Chaturvedi, B., Scheinberg, A., 2011a. The economics of the informal sector in solid waste management. CWG-Collaborative Working Group on Solid Waste Management in Low-and MiddleIncome Countries, GIZ-Deutsche Gesellschaft Für Internationale Zusammenarbeit (GIZ) GmbH. [Online]. http://www.giz.de/de/downloads/giz2011-cwg-booklet-economicaspects.pdf (Accessed 22 September 2015).

Gunsilius, E., Spies, S., García-Cortés, S., Medina, M., Dias, S., Scheinberg, A., Sabry, W., Abdel-Hady, N., Florisbela dos Santos, A., Ruiz, S., 2011b. Recovering resources, creating opportunities: Integrating the informal sector into solid waste management. Eschborn, Deutsche Gesellschaft für Internationale Zusammenarbeit (GIZ): Eschborn, Germany, March 2011, pp. 54. [Online]: https://www.giz.de/de/downloads/giz2011-en-recycling-partnerships-informal-sector-final-report.pdf (Accessed 1 February, 2016).

Gutberlet, J., 2008. Recovering resources - recycling citizenship: urban poverty reduction in Latin America. pp. 164. Aldershot, UK: Ashgate.

Gutberlet, J., 2015. More inclusive and cleaner cities with waste management co-production: Insights from participatory epistemologies and methods. Habitat International, 46, 234-243.

Humphrey, J., Navas-Alemán, L., 2010. Value chains, donor interventions and poverty reduction: A review of donor practice. IDS Research Reports, 2010 (63), 1-106.

ILO, 2004. Addressing the Exploitation of Children in Scavenging (Waste Picking): a Thematic Evaluation of Action on Child Labour. Global Synthesis Report for the International Labour Organisation's International Programme on the Elimination of Child Labour (IPEC). ILO: Geneva, ISBN 92-2116661-9. [Online]. http://www.ilo.org/ipecinfo/product/download.do?type=document\&id=459 (Accessed 1 February, 2016).

Iskandar, L., Tjell, J.C., 2009. Cairo: A colossal case of waste mismanagement to learn from. Waste Management \& Research, 27, 939-940.

Kaplinsky, R., Morris, M., 2001. A handbook for value chain research. IDRC Canada. [Online] http://asiandrivers.open.ac.uk/documents/Value_chain_Handbook_RKMM_Nov_2001.pdf (Accessed 1 March, 2016)

KIT (Royal Tropical Institute), FaidaMaLi and IIRR (2006). Chain empowerment: supporting African farmers to develop markets pp. 230. Royal Tropical Institute (KIT), Amsterdam; Faida Market Link, Arusha; and International Institute of Rural Reconstruction, Nairobi. [Online] https://www.cordaid.org/media/publications/Chain_Empowerment_2.pdf (Accessed 10 March, 2016)

Kogut, B., 1985. Designing global strategies: Comparative and competitive value-added chains. Sloan management review, 26(4), 15-28.

Lazzarini, S., Chaddad, F., Cook, M., 2001. Integrating supply chain and network analyses: the study of netchains. Journal on Chain and Network Science, 1 (1), 7-22.

Linzner R., Lange U., 2013. Informal sector activities in waste management: a literature review. Proc. ICE - Waste and Resources Management, 166, WR2, 69-83.

Mavropoulos, A., Wilson, D.C., Appelqvist, B., Velis, C.A., Cooper, J., 2014. Globalisation and Waste Management - Final Report from the ISWA Task Force. International Solid Waste Association (ISWA). Vienna: Austria. [Online] http://www.iswa.org/fileadmin/galleries/Task_Forces/TFGWM_Report_GWM_LR.pdf (Accessed 1 February 2016).

Medina, M., 2000. Scavenger cooperatives in Asia and Latin America. Resources, Conservation and Recycling, 31(1), 51-69.

Medina, M., 2007. The world's scavengers: salvaging for sustainable consumption and production. pp. 256. Lanham, US: AltaMira Press. 
Mueller, A.W., 2005. A Value Chain Analysis of Cardboard Collection in Inner City Durban, South Africa. Durban: School of Development Studies, University of KwaZulu-Natal. |Online] http://researchspace.ukzn.ac.za/xmlui/bitstream/handle/10413/2932/Mueller_Adria_Whitney_2005.pd f? sequence $=1$ (Accessed $1^{\text {st }}$ February 2016).

Porter, M.E., 1985. Competitive Advantage: Creating and Sustaining Superior Performance. New York: The Free Press.

Porter, M.E., 1990. The Competitive Advantage of Nations. London: Macmillan.

Rakiman U.S., Rasi R.J.R.M., Latiffi A.A., 2014. Value chain analysis: the insight of aluminium recycling. Australian Journal of Basic and Applied Sciences, 8(15) 377-382.

Rigasi Y.A., Badamasi A.G., Abdulkarim B.I., 2015. The evolution of value chains and recycling opportunities in the informal management of municipal solid waste of Kaduna metropolis, Nigeria. Biological and Environmental Sciences Journal for the Tropics, 12(1), 498-505.

Riisgaard, L., Ponte, S., 2011. Pro-Poor Value Chain Development: 25 Guiding Questions for Designing and Implementing Agroindustry Projects. A Practitioner's Guide. Prepared by Danish Institute for International Studies, United Nations Industrial Development Organization (UNIDO). Vienna, Austria.

Rodic, L., 2015. Informal Waste Sector. Topic Sheet 14, in UNEP (2015), Global Waste Management Outlook, op. cit., pp 176-180.

Rodic, L., Romero, V., Filho, C.S., 2015. EPR initiatives form countries outside the 'usual' OECD countries. Topic Sheet 12, in UNEP (2015), Global Waste Management Outlook, op. cit., pp 160-165.

Samson, M., 2010. Reclaiming Reusable and Recyclable Materials in Africa - A Critical Review of English Language Literature. Women in Informal Employment Globalizing and Organizing (WIEGO), Urban Policy Research report, No. 16. [Online] http://wiego.org/sites/wiego.org/files/publications/files/Samson_WIEGO_WP16.pdf (Accessed 4 February 2016).

Scheinberg, A., 2011. Value added: models of sustainable recycling in the modernisation of waste management systems. PhD thesis. Wageningen University, Gouda, The Netherlands, pp. 120. [Online] http://edepot.wur.nl/179408 (Accessed 22 September 2015)

Scheinberg, A., 2012. Informal sector integration and high performance recycling: evidence from 20 cities. Women in Informal Employment Globalizing and Organizing (WIEGO) Working paper (Urban Policies) No 23. [Online] http://wiego.org/sites/wiego.org/files/publications/files/Scheinberg WIEGO WP23.pdf (Accessed 22 September 2015).

Scheinberg, A., Simpson, M., Gupt, Y., Anschütz, J., Haenen, I., Tasheva, E., Hecke, J., Soos, R., Chaturvedi, B., Garcia-Cortes, S., Gunsilius, E., 2010. Economic Aspects of the Informal Sector in Solid Waste Management. GTZ (German Technical Cooperation - now GIZ): Eschborn, Germany. [Online] via https://www.giz.de/en/mediacenter/publications.html - go to 'search in the Publication database' and use the title as the search term (Accessed $1^{\text {st }}$ March 2016).

Scheinberg, A., Spies, S., Simpson, M.H., Mol, A.P.J., 2011. Assessing urban recycling in low- and middle-income countries: Building on modernised mixtures. Habitat International, 35, 188-198.

Scheinberg, A., Savain, R., 2015. Valuing Informal Integration: Inclusive Recycling in North Africa and the Middle East. Deutsche Gesellschaft für Internationale Zusammenarbeit (GIZ) GmbH. [Online] via https://www.giz.de/en/mediacenter/publications.html - go to 'search in the Publication database' and use search term 'Valuing' (Accessed $1{ }^{\text {st }}$ February 2016).

Scheinberg, A., Simpson, M., 2015. A tale of five cities: Using recycling frameworks to analyse inclusive recycling performance. Waste Management \& Research, 33, 975-985.

Schluep, M., 2014. Informal waste recycling in developing countries. Chapter 29 in: Handbook of Recycling Edited by: Worrell, E. and Reuter, M.A., pp 439-444. Elsevier ISBN: 9780123964595.

Shaker, B., 2014a. Structural Integration of the Informal Sector in Municipal Solid Waste Management - A Case Study/ Story from Cairo, Egypt. Sweepnet Conference, September 2014. [Online]: 
http://www.sweepnet.org/sites/default/files/Presentation\%20on\%20Egyptian\%20experience\%20EN.pdf (Accessed $15^{\text {th }}$ June 2015).

Shaker, B., 2014b. TWO in ONE: A model from Cairo capturing CSR and Social Entrepreneurship Together; "Mokattam Recycling School". [Online] http://www.sweep-net.org/two-one-model-cairocapturing (Accessed 29 February, 2016)

Staffeld, R., 2010. Value Chain Analysis in the Plastic Recycling Sector in Cairo and Alexandria. IPConsult Germany. Eschborn: GTZ PDSP-Egypt.

Sturgeon, T. J., 2001. How Do We Define Value Chains and Production Networks? IDS Bulletin, 32 (3), 918.

Trienekens, J.H., 2011. Agricultural value chains in developing countries a framework for analysis. International Food and Agribusiness Management Review. 14 (2) 51-82.

UNEP, 2015. Global Waste Management Outlook. Editor-in-Chief: Wilson, D.C. Authors: Wilson, D.C., Rodic, L., Modak, P., Soos, R., Carpintero, A., Velis, C.A., Iyer, M.,, Simonett, O. Prepared for UNEP and ISWA. Osaka: UNEP. |Online] http://www.unep.org/ietc/InformationResources/Events/GlobalWasteManagementOutlookGWMO/tab id/106373/Default.aspx (Accessed $1^{\text {st }}$ February 2016).

Velis, C.A., Wilson, D.C., Rocca, O., Smith, S.R., Mavropoulos, A., Cheeseman, C.R., 2012. An analytical framework and tool ('InteRa') for integrating the informal recycling sector in waste and resource management systems in developing countries. Waste Management \& Research, 30 (9 Suppl), 43-66.

Will, M., Vogelzang, M., Wanyonyi, M., Hoeffler, H., 2008. Capacity Development Concept for Value Chain Development. GTZ Private Sector Development Project (PSDP)-Kenya.

Wilson, D.C., Araba, A.O., Chinwah, K., Cheeseman, C.R., 2009. Building recycling rates through the informal sector. Waste Management, 29, 629-635.

Wilson, D.C., Rodic, L., Cowing, M.J., Velis, C.A., Whiteman, A.D., Scheinberg, A., Vilches, R., Masterson, D., Stretz, J., Oelz, B., 2015. 'Wasteaware' benchmark indicators for integrated sustainable waste management in cities. Waste Management, 35 (1), 329-343.

Wilson, D.C., Rodic, L., Scheinberg, A., Velis, C.A., Alabaster, G., 2012. Comparative analysis of solid waste management in 20 cities. Waste Management \& Research, 30 (3), 237-254.

Wilson, D.C., Velis, C., Cheeseman, C., 2006. Role of informal sector recycling in waste management in developing countries. Habitat International, 30, 797-808.

Wilson, D.C., Velis, C.A., Rodic, L., 2013. Integrated sustainable waste management in developing countries. Proceedings of the Institution of Civil Engineers, Waste and Resource Management, 166, WR2, 52-68.

Womack, J.P., D.T Jones., 1996. Lean Thinking: Banish Waste and Create Wealth in Your Corporation. New York: Simon and Schüste.

Zaki, T., Kalafi, G K., Mina, M B., El-Halim, M A., Sabler, M., 2013. Annual Report for Solid Waste Management in Egypt. [Online]. http://cairoclimatetalks.net/sites/default/files/EN\%20Annual\%20Report\%20on\%20Waste\%20in\%20E gypt 2013.pdf (Accessed 22 $2^{\text {nd }}$ September 2015). 